E Q U I L I B R I U M

Volume 6 IsSue 3, 2011

IS S N $1689-765 \mathrm{X}$

Łukasz Goczek

University of Warsaw, Poland

\title{
Federal Policy Responses to the 2007-2009 \\ US CREDit CRUNCH
}

JEL Classification Codes: E00, E44, E50, E65

Keywords: credit crunch, liquidity, finance, United States, monetary policy

\begin{abstract}
This paper discusses the key characteristics of the U.S. financial crisis 2007-2009 and focuses on the Federal Policy Response to the lack of liquidity in the financial sector known as the "Credit Crunch". The surprising depth of the crisis required unprecedented policy measures to be used in order to tackle the mounting liquidity problems in banks and prevent the subsequent credit crunch from taking its toll in the real economy. This required extension of monetary powers of the Federal Reserve and Treasury, which was unmatched in history. The policy response to credit crunch and house price bust was especially important given the fact that recessions following such events tend to be much deeper and longer than any other types of recessions. More importantly, however, the analyses of the current policy responses will determine which form financial markets will take in the next few decades, thus how vulnerable the world economy will be to next disruptions and liquidity problems.
\end{abstract}

\section{Introduction}

At the time of writing, the 2007-2009 global financial crisis seems to be over, although the U.S. economy shows signs of a still unsteady revival. Despite the not so distant past, a scientific account of what happened in the financial markets recently is vitally important. There are two reasons why it is the case. First, the consequences of the financial crisis are immense, not only for the financial sector, but also for the real economy. More importantly however, the analyses of the current policy responses will determine which form the financial markets will take in the next few decades, thus how vulnerable the world economy will be to the next disruption. Therefore, the aim of the article is to examine the federal response to mortgage distress during the 2007-2009 U.S. financial crisis. 
The article briefly documents some features of the boom and bust in the U.S. and then proceeds to discuss and evaluate the actions of the federal authorities taken to provide liquidity to the markets and failing banks, to regulate failing financial institutions and provide them with new capital. The surprising depth of the crisis required unprecedented policy measures to be used in order to tackle the mounting liquidity problems in banks and prevent the subsequent credit crunch from taking its toll in the real economy. This required extension of monetary powers of the Federal Reserve and Treasury which was unmatched in history. Most of these actions were unprecedented in both routine and size. Currently, the overall federal commitments in different stimulus and monetary programs reached an astonishing value of $\$ 13$ trillion USD - almost whole US GDP in one year.

The article devotes more focus to monetary policy and less focus on fiscal policy. While there is essentially no dispute within macroeconomics that GDP rises and unemployment falls when the government expands its expenditures, the failure of the government to add to aggregate demand in 2009, when the need seemed most intense, seems to make again a point that government purchases are irrelevant to stabilization policy. It's not that fiscal policy is ineffective in the area of rising GDP, but the fact that the government is incapable of executing a rapid and sufficiently large increase in purchases makes fiscal policy an ineffective stabilization policy tool. ${ }^{1}$

The policy response to credit crunch and house price bust was especially important given the fact that recessions following such events tend to be much deeper and longer than any other types of recessions (Reinhardt, Rogoff 2011, Jordà et al. 2010). More importantly however, the analyses of the current policy responses will determine which form the financial markets will take in the next few decades, thus how vulnerable the world economy will be to next disruptions and liquidity problems.

\section{Features of the 2007-2009 financial crisis}

The pattern of the 2007-2009 financial crisis is no different from the past, since one could point out similar pattern as almost every other historical mania, panic, and crash before this one. The first and probably most important cause of the crash is prolonged and undisclosed availability of cheap funds. Whether this was the effect of Federal Reserve's mistake in keeping the federal interest rate too low (Taylor 2009), the mistake motivated by the desire to avoid deflationary spi-

${ }^{1}$ Cogan and Taylor (2010) present a case, that the fiscal stimulus has not been too small, but rather that it failed to increase government consumption expenditures and infrastructure spending as expected from such a large package. A consideration of the counterfactual event that there had not been a fiscal stimulus supports the hypothesis purchases would have been about the same in the absence of fiscal stimulus. 
rals, or whether the global "savings glut" from countries following export-driven growth forced global interest rates down, is unknown at this point of time. Reinhart and Reinhart (2010) make a case, that in an open economy, the central bank has less scope to influence the path of globally traded financial assets. To support this view, they empirically find a lack of association between the position of monetary policy and the longer-term rates which matter for spending during both the past decade and over the course of the past century. The important thing is that whatever the underlying cause, obtaining funds for risky investment became extraordinarily cheap in this period. In other words, it became very easy to take excessive risk. Jordà et. al. (2010) applied new statistical tools to describe the temporal and spatial patterns of crises and identify five episodes of global financial instability in the past 140 years. They show that credit growth tends to be elevated and natural interest rates depressed in the run-up to global financial crises and this was the case as well in the years preceding the crisis.

The second probable cause was financial innovation that has occurred for two decades before the crash, bringing about potential to exacerbate systemic risks and "wasteful" use of private resources by financial innovators in rent-seeking behavior (Lerner, Tufano 2011). The cheap funding and unknown nature of new financial assets, including securitization, the innovative originate and distribute banking model, credit default swaps and other OTC derivatives led to excessive optimism of the asset value and a subsequent pricing bubble in real estate and commodities. This was, of course, not enough for an asset bubble to be created, since the level of interest rates or financial innovations are just two of the many factors taken into account by individuals in financial decision-making. The explanations for the flawed choices in this area can be grouped into three categories (Mishkin 2009):

- The agency problem - executives of financial institutions and banks knew and understood the risks they were taking, but decided to get ahead with taking it, based on the notion that they could reap the gains and profits and leave the losses and risks associated with inevitable crash to others;

- The externalities problem - executives of financial institutions understood the risks they were taking, yet went ahead because they did not take account of the social risks and costs of their own actions and failures of their institutions, since they were rewarded for taking more risks than it was socially desirable;

- The irrationality problem - executives of financial institutions did not fully understand the risks they were taking, they reacted emotionally and irrationally to an uncertain series of financial innovations. This meant an excess of optimism during price increase and excessive pessimism, if not panic, whenever the trend turned around.

Whichever is the most powerful framework to explain the U.S. asset bubble, sooner or later due to debt overhang, every bubble must burst and price collapse 
occurs. The result of such collapse is an extreme uncertainty about fundamental asset values, which could potentially lead to excessive pessimism on the part of households and investors that erodes asset prices even further. As in every other bubble burst, the financial sector is the first and hardest to be hit. This is so, because of the very nature of financial institutions. The very role of banking institutions as intertemporal intermediaries entails the presence of illiquid long-term assets (mainly credit to the private sector) and extremely short-term liabilities (mostly household deposits) on their balance sheets. Unsurprisingly, even conservative financial institutions tend to be highly leveraged and a sudden decline in asset quality quickly erodes their equity. However, the long period of small frictions in the financial markets, large macroeconomic shocks, and low inflation, known as the "Great Moderation" made everyone in the market excessively optimistic. In fact, there was something akin to an irrational belief that everything will be always as planned caused some of the intuitions to be leveraged to unprecedented levels (Taylor, Williams 2009). In their case, even a slightest adverse development in the economy made them insolvent, causing fire sales and asset price collapse. Figure 1 shows the gist of the exposition in this chapter.

Figure 1. Key characteristics leading to the crisis

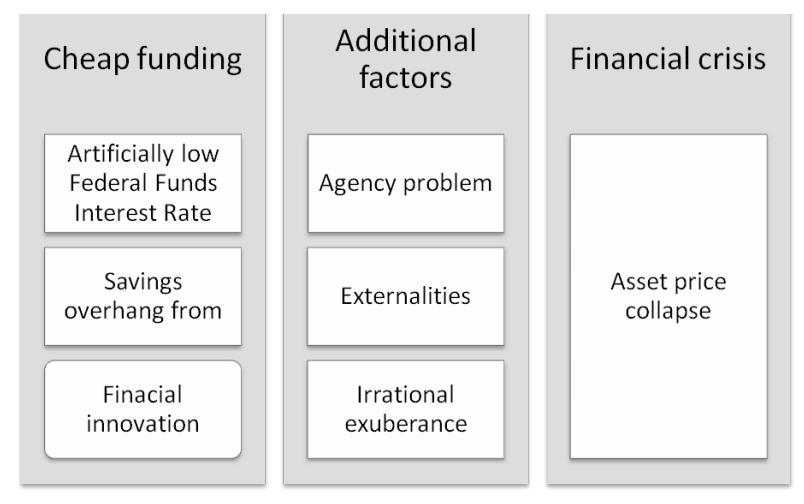

Source: own work.

\section{Asymmetric information during financial crisis}

A modern approach to financial institutions emphasizes the role of asymmetric information during financial crises such as the 2007-2009 crisis. This framework is based on the observation, that the very function of the financial system is to direct funds to entities with good investment opportunities based on collecting and processing information on risk. Historically, financial intermediaries such as banks have played a major role in reducing the asymmetry of information about risk in the credit markets, however, during financial crises this role cannot be carried out properly. The information flows break off and price/risk discovery is 
distorted. At these times asset valuation becomes extremely complex, if not impossible. This phenomenon is reflected in high risk spreads and unwillingness to buy assets, frequent characteristics of such episodes. These of course are rational responses to the increased uncertainty resulting from the disruption of information.

These distinctive features make financial institutions prone to panics and "runs", once price collapse of assets is set in motion. A run could result in sudden and unexpected financial accelerator for the whole financial system creating huge systemic risk. This is so, because runs pose the potential for huge externalities to other financial institutions, since financial institutions tend to be highly co-dependent - assets of one institution are debts of other institutions. During a crisis, in the asymmetric information environment, investors scramble for liquidity at the slightest sign of trouble, exiting illiquid investments and seeking liquid investments, mostly money market instruments including cash. As Caballero (2009) points out, when acute financial distress emerges in parts of the financial network, it is not enough to be informed about those partners, as it also becomes important to learn about the health of their trading partners. As conditions continue to deteriorate, banks must learn about the health of the trading partners of the trading partners of the trading partners, and so on. At some point, the cost of information gathering becomes too unmanageable for banks, uncertainty spreads through the financial system, and they have no option but to withdraw from loan commitments and illiquid positions, causing further deterioration in prices. A flight-to-quality ensues and the financial crisis contagion spreads.

This flight can be exacerbated by two types of risks that are particularly important for understanding financial instability during the Credit Crunch. The first is valuation risk (Mishkin 2009): the managers of financial institutions, suddenly realizing the complexity of a security or the uncertainty of its underlying creditworthiness, find that they have trouble assessing the value of a given asset. This is a phenomenon known as Knightian uncertainty. It arises, when unusual shocks to untested financial innovations lead agents to become uncertain about their investments causing them to disengage from markets and increase their demand for liquidity.

A new feature of the current crisis as opposed to previous ones was the role of "origin to distribute banking" model and Credit Default Swaps (CDS), For example, the Knightian risk has been central to the repricing of many structured credit products during the turmoil of the past year, when investors have struggled to understand how potential losses in subprime mortgages might filter through the layers of complexity that such products entail. CDS, on the other hand, added to problems in the shadow banking system, especially in the insurance sector ${ }^{2}$.

${ }^{2}$ It could be also pointed out, that the institutions themselves added to this problem by enacting many of their risky investment with the use of Special Investment Vehicles. This made the situation even more opaque to investors. These off balance sheet entities were designed to 
As insurance companies were downgraded, rating declines created "Credit Events" as defined in CDS Contracts and caused credit institutions called for more collateral, intensifying even further the ongoing fire sales of assets and even further exacerbating the liquidity problem. The extreme vulnerability of highly leveraged financial investors to sudden stops in short-term financing can lead to cascades of liquidation. A negative shock to the balance sheets of asset-holders causes them to make fire-sales and liquidate assets at any price, thus instantly lowering prices, further deteriorating balance sheets, culminating in a crisis. What is equally important, the returns to those who have liquid cash at such times can be extraordinarily high, which causes further increases in flight to liquidity.

Shleifer and Vishny (1992) defined a fire sale as a forced sale of an asset at a price disjoined from its fundamental value. This asset sale is forced in the sense that the seller faces liquidity problems and cannot pay its creditors without selling their assets. The price is disjoined from its fundamental value because the highest potential bidders are themselves indebted and cannot borrow more to buy the asset. In reality, these potential buyers, rather than buying the asset, might be selling similar assets themselves. Assets are then bought by outsiders to the market who, knowing that they have less knowledge with the fire sold assets, are only willing to buy at prices that are much lower than the fundamental value. Assets sold in fire sales can trade at prices far below value in best use, causing severe losses to sellers. This self-reinforcing process can lead to downward spirals in asset prices and net worth of market participants. One consequence of the fire sale is that it may depress asset values so much that the financial institution becomes insolvent. This may cause a sudden run on the bank, which may cause more assets to be unloaded on the market, further depressing the price.

The second type of risk central to the understanding of credit crunch is macroeconomic or systemic risk - an increase in the probability that a financial disruption will cause significant deterioration in the real economy. In particular, strains in financial markets can have significant spillovers to the firms and households, thereby having adverse consequences on output and employment. Because of widespread effects of fire sales, risk becomes systemic. Through this process, asset fire sales and the deterioration of the net worth of firms and financial institutions can severely undermine financial intermediation, leading to reductions of real investment and output as argued by Shleifer and Vishny (2010). Furthermore, an economic downturn tends to generate even greater uncertainty about asset values, which could initiate adverse feedback in which the financial disruption restrains economic activity; such a situation could lead to greater uncertainty and increased financial disruption, causing a further deterioration in macroeconomic activity, etc. This regularity is known as the financial accelerator

evade capital requirements. These innovations were globally linked through financial globalization. This increased global systemic risk. 
(Bernanke, Gertler 1989; Bernanke, Gertler, Gilchrist 1996, 1999 propose different explanations for the phenomenon). The quality of balance sheets of households and firms comprise a key element of the financial accelerator mechanism, because some of the assets of each borrower may serve as collateral for its liabilities. These mechanisms work only as long as the collateral is of sufficient quality; during macroeconomic downturns, the value of collateral may fall, problems of adverse selection and moral hazard again become central, and lenders become much less willing to lend (Mishkin 2011).

The high-risk spreads and reluctance to credit that are characteristic of such episodes are natural responses to the increased uncertainty resulting from the disruption of information. In fact, a rational response to asymmetric information problem during the crisis makes things worse. Financial institutions' run to liquidity cause them to increase their currency holdings, increase reserves, and reduce the amount of credit extended to the economy, anything done to reduce their leverage. This will imply both low prices for illiquid assets and high interest rates charged for lending to the real economy. Investors' self-fulfilling expectations cause them to limit the funding to the hardest hit sectors of the economy, aggravating the already serious liquidity problem. In this way, illiquidity can depress lending to the whole private sector, including credit institutions themselves, since at this point in time when the financial accelerator is in motion it could be too late to hedge just against valuation risk, as the most worrying effect of drying up liquidity is lack of credit to the private sector. Therefore, any policy response to the crisis must entail bringing liquidity back to the markets, which is the root problem behind the financial accelerator. The problem of lack of liquidity has serious consequences and asset wealth erosion associated with Knightian uncertainty and valuation risk is just one of them. However, some of this uncertainty is associated with broker institutions themselves, thus the first step for policy makers will be to reduce this effect with the use of guarantees to jump-start the market back to operation. Only then they can start unloading their direct interventions in the market.

\section{Federal response - restoring liquidity during financial crisis}

Before advancing further, there is necessity to explain the concept of liquidity. There are two kinds of liquidity: market liquidity and funding liquidity. An asset has market liquidity if it is unproblematic to trade, that is, has a low spread, small price impact, high resilience, buyers/sellers are easy to find (important factor in Over The Counter markets). A financial entity has good funding liquidity if it has enough available funding from its own equity or from collateralized loans. Thus, the concept of liquidity risk is straightforward: 
- Market liquidity risk - the risk that the market liquidity worsens when there is a make transaction in the market.

- Funding liquidity risk - the risk that an entity cannot fund his position and is forced to unwind.

When liquidity risk worsens, a levered financial fund may lose its access to funding from its bank (funding liquidity risk) and must sell its securities as a result. Or, from the bank's perspective, depositors may withdraw their funds, the bank may lose its ability to borrow from other banks, or raise funds via debt issues. Before the event, banks might expand their balance sheets excessively if they or investors make mistakes or if they fail to take into account the cost of fire sales. After the event, fire sales undermine the ability of financial institutions and firms to lend and to borrow by reducing their net worth and market liquidity worsens throughout the financial system. The presence of such externalities provides a justification for policy interventions. During fire sales, many key financial institutions such as banks are driven out of the credit market due to their inability to access capital and are forced off the market (market liquidity risk). This essentially entails a breakdown of the credit system.

Federal Reserve has responded to the breakdown in the credit system associated with liquidity in four key ways. First, it exercised its traditional role as lender of last resort - both using Open Market Operations and newly adapted approaches. Starting in mid-August 2007, the Fed lowered the discount rate to just 50 basis points above the federal funds rate target from the normal 100 basis points and arrived at 25 basis points. The credit-tightening and the rise in the cost of private credit despite the radical expansion of monetary policy had led to an often expressed view that monetary policy was not effective during the financial crisis. The reason for this view is that there is a notable asymmetry in the design and implementation of monetary policy: nominal interest rates cannot be negative. During boom times, when the economy is overheating and inflation threatens to rise to undesirable levels, the central bank can raise the official policy rate (a short, risk-free nominal interest rate) to any level it deems necessary.

During economic downturns, when excess capacity rises and deflation threatens, the official policy rate can be cut no further than zero. There is a strong case that the zero lower bound has been a binding constraint on central bank interest rate setting, also during current financial crisis. In fact, some researchers including Taylor (2009) himself, used the Taylor rule, to show that optimal level of interest rates is negative. If a further stimulus is desired, unconventional monetary policy, such as quantitative easing and credit easing must be resorted to $^{3}$. In this notion, the Federal Reserve intervened starting in the summer of 2007

\footnotetext{
${ }^{3}$ Quantitative easing is an increase in the size of the balance sheet of the central bank through an increase it is monetary liabilities (base money), holding constant the composition of its assets. Asset composition can be defined as the proportional shares of the different finan-
} 
by facilitating mergers of troubled financial institutions and lending to others against risky collateral. This series of interventions successfully delayed worsening of the crisis by over a year. When the financial crisis started in August 2007, central bank actions to contain it seemed to be working. Many officials, although still concerned about the disruption to the financial markets, hoped that the worst was over and that the financial system would begin to recover. In September 2008, however, as bad news about the housing market and the values of mortgage-backed securities became evident, the markets collapsed. The vocal point was the Lehman Bank collapse - the federal government, despite expectations and promises, did not fare as well in providing funding liquidity for failing institutions as everyone had hoped. The failure has resulted in the need for the fiscal stimulus package to be much bigger than the expected funding needs for the failing institutions. After these events unfolded there was a cycle of price collapses and deleveraging described by fire sales models, driven by both capital withdrawals because of declining collateral values and growing haircuts because of increased risk. Before the Lehman bankruptcy, in contrast, liquidity provision by the Federal Reserve kept most of the specialist buyers in the market. With natural buyers of distressed securities withdrawn after Lehman, security prices and credit went into a free fall.

The second policy response, devised in order to stop the fire sales, the Federal Reserve provided liquidity directly to borrowers and investors in key credit markets, with the explicit aim of restarting securitized lending using Federal Reserve financing. First, Fed expanded the scope of collateral acceptable to pledge to secure federal financing (on Sept. 14, 2008). Second, Fed secured non-recourse loan to depository institutions and bank holding companies to buy eligible commercial paper from money market funds (Sept. 19, 2008). Third, it provided liquidity for money market funds to meet redemptions triggered by Lehman bankruptcy Treasury guarantee of money market funds (Sept. 19, 2008; extension April 1, 2009). Implicitly this amounted to increase government borrowing to replace the missing private sector borrowing. The Federal Reserve, in particular, has implemented large liquidity injections into the credit markets in order to restore lending. While at the outset this should have a direct effect on lending this was not the case - banks engaged in precautionary hoarding of liquidity or purchased assets at prices well below the level at which new lending becomes attractive ${ }^{4}$. At the same time, however, the financial crisis now transformed into a global crisis that caused a sharp drop in economic activity in the

cial instruments held by the central bank in the total value of its assets. An almost equivalent definition would be that quantitative easing is an increase in the size of the balance sheet of the central bank through an increase in its monetary liabilities that holds constant the (average) liquidity and riskiness of its asset portfolio.

${ }^{4} \mathrm{~A}$ further problem with providing loans or equity to banks is that the government may end up supporting institutions that ultimately fail and perhaps encourage some of the desperate 
United States with the unemployment rate remaining persistently high even after the world economy started to recover. The world-wide recession that resulted from the financial crisis turned out to be the most severe economic contraction since the world-wide depression of the 1930s (Mishkin 2011).

The third policy response, conducted jointly with the Department of Treasury, were direct purchases of agency debt in the aftermath of the Lehman bankruptcy. This became important support for key market institutions (so-called market creators), however, this was further extended in the form direct capital injections for major failing financial institutions in the market such as Bank of America, Citibank, and AIG, in order to limit the asset-price collapse induced by asset firesales of bankrupting firms (the infamous bail-out). Over the course of the crisis, the Fed broadened its provision of liquidity to the financial system well outside of its traditional lending to depository institutions. This even lead Paul Volcker, a former Chairman of the Federal Reserve, to describe the Fed's actions as going to the "very edge of its lawful and implied powers." (Shleifer, Vishny 2010).

The fourth policy response was countering of uncertainty by providing liquidity to market makers, brokers, thus restoring markets. Furthermore, the FED chairman aimed at reducing monetary policy uncertainty by committing to near zero-bound federal funds rates for a long time after the crisis. This entailed a careful management of expectations in which central banks committed to keep their policy rate at very low levels for a long period of time.

Essentially, the policy response caused the Federal Reserve to become both a lender to private sector and the biggest holder of risky securities. By accepting risky collateral as a guarantee for loans on advantageous terms, and removing massive quantities of unsold securities from the market, the Federal Reserve stabilized banks and the financial system by the end of March of 2009. The price of risk fell. The economy remained slow, but a depression was avoided. Importantly, the macroeconomic outlook was much worse in March 2009 than before, but the fact that financial markets stabilized quickly suggests that liquidity problems caused by fire sales were indeed severe after Lehman, and they had to be addressed through public interventions.

This means that nonconventional monetary policy proved to be effective during the recent financial crisis, but this does not mean we should preclude that conventional policy is ineffective. The problem during the financial crisis episode with conventional monetary policy is not that it was ineffective, but that the adverse shock from the financial crisis was so serious that it weighed down the ability of conventional monetary policy to neutralize it. Mishkin (2009) makes a case, that interest rates would have been higher if the federal funds rates had been higher, but also credit spreads would have widened by even more than they

intermediaries to gamble with government funds by taking on more risk, however this was not the case in the U.S. 
did during this crisis because the weaker economy would have made conditions in financial markets even more stressed posing more risk to liquidity.

In assessing empirically the role of liquidity provision, some researchers argue that there was only a modest effect from these types of programs. Taylor and Williams (2009), for example, do not find that the actual lending from the Term Auction Facility had any impact on easing credit markets. This conclusion has attracted a lot of attention after Taylor published it in his well sold book (published all over the world, including Poland) Taylor (2009). However, other researchers have proved this preemptive conclusion wrong by arguing that financial markets act in response to the announcements of programs, rather than the actual lending and because of non-stationary of the data that the dependent variable in the analysis should use changes in spreads and not levels. McAndrews et al (2008) found that announcements about Term Auction Facility did significantly lower credit spreads, and other research supports the conclusion that the TAF and other credit facilities helped lower interest rates (Wu 2008, Christensen, et al. 2009, Sarkar, Shrader 2010).

Baba and Packer (2009) and McAndrews (2009), Goldberg, Kennedy and Miu (2010) find that the U.S. dollar swap facilities did help improve the performance of the dollar swap markets. Using a similar event-study methodology, Ait-Sahalia et al. (2010) found that liquidity provision in the United States, United Kingdom, and Japan, did lower interbank risk premiums. All in all - this empirical research suggests that liquidity provision stabilized financial markets during this crisis. Gujral, et al (2011) report that even as banks and financial intermediaries suffered large credit losses in the financial crisis of 2007-2009, they raised substantial amounts of new capital, both from private investors, but mostly through government-funded capital injections. However, on closer inspection the composition of bank capital shifted radically from being based on common equity to the one based on debt claims such as preferred equity and subordinated debt. Research on the impact of the Fed's large-scale asset purchases during the global financial crisis by Gagnon, et al (2010), find that these programs lowered long-term bond rates relative to short rates on the order of 50 basis points, and lowered securities interest rates even further by improving liquidity in this market, thereby having a substantial impact on residential mortgage rates (Mishkin 2011). This is important given evidence presented in Campello et al. (2009). The authors have found that during the crisis credit constrained firms plan deep cuts in tech spending, employment and capital spending. Investment in profitable projects is restricted during such credit and along these lines they report, that the executives surveyed declare they would cancel or postpone their planned investment. 
Figure 2. From the crisis to the FED response

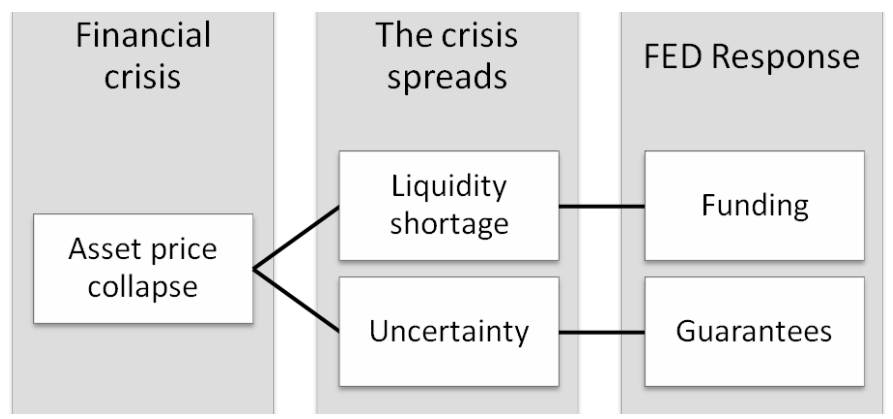

Source: own work.

The line of thinking shown in this and previous chapter can be briefly summarized in figure 2 .

\section{Conclusions and policy implications}

Although there is much to be held for the view that government sometimes does more harm than good, there is also much to make a case that free markets do not always deliver efficient outcomes and this is especially true during the times of crisis. In economics, there is a long history of recognizing specific market failures and recommending policies to correct them and financial sector seems to be one of the most prominent places for negative externalities when it comes to valuation and systemic risk. Along these lines, the article has argued that the U.S government has taken up an unprecedented intervention both in size and in scope to limit the consequences of the financial crisis of 2007-2009. These new policy measures have led to large federal expenditures and even larger commitments on the side of various government branches. Summing up, it seems that the Federal Reserve managed the crisis well in terms of providing liquidity to the markets and thus the financial crisis appears to have been a liquidity crisis, not just a solvency crisis.

However, the policy implications do not stop just at costs of the intervention. Besides the huge loss of aggregate output as a result of the worldwide recession, the global financial crisis suggests that there are likely to be additional costs of the intervention that will possibly become higher in the future. To discuss this, let us state a couple o stylized facts:

- The budget deficits of governments' sharply deteriorate during crises;

- Financial crises are characteristically followed by sluggish growth;

- The exit strategy for central banks from these new and nonconventional monetary policies may be unknown at this point or may get in the way of successfully managing the monetary policy in the future. 
The stylized facts can have serious consequences for the fiscal deficits of the U.S. government, consequences that are unknown at this stage. As pointed out by Reinhart and Rogoff (2011), the aftermath of financial crises is almost always a sharp increase in government indebtedness. We have seen exactly this situation in the aftermath of the current crisis. The massive bailouts of financial institutions, fiscal stimulus packages, and the sharp economic contractions that reduced tax revenue that occurred throughout the world have adversely affected the fiscal situation for many countries. Reinhart and Reinhart (2011) present evidence that public debts in the advanced economies have surged in recent years to levels not recorded since the end of World War II, surpassing the heights reached during the First World War and the Great Depression. At the same time, private debt levels, particularly those of financial institutions and households, are in uncharted territory and are (in varying degrees) a contingent liability of the public sector in many countries.

Historically (Reinhardt, Rogoff 2011), high leverage episodes have been associated with slower economic growth and a higher incidence of default or, more generally, restructuring of public and private debts. Moreover, the strong monetary policy response by the FED has an adverse potential effect in making dollar a carry currency. This could have serious long-term effects for the revival of the U.S. economy and could possibly fuel food and raw material bubbles. Another danger from aggressive pegging monetary policy to the zero bound is that it might boost inflation expectations for a long time. This unanchoring of inflation expectations could then lead to significant inflation in the future because the behavior of current inflation is significantly influenced by the public's expectations about where inflation is likely to head in the long run.

Furthermore, it could be pointed out that both quantitative easing and credit easing are policies that have not been used in the past. Given the lack of previous experience, it is very difficult to evaluate the consequences of these measures with reasonable certainty. Quantitative easing is a high-risk strategy. Like simple debt monetization, quantitative easing runs the risk of quickly going too far or too close. Introducing too much money into the financial system can cause high inflation. On the other hand, it could be that these unprecedented policies may be insufficient at the zero bound in the presence of binding liquidity constraints, banks will remain unwilling to lend, the crisis could continue, and that is what happened in Japan during its prolonged deflationary period. A question comes to mind, what other policies could be exercised in order to prevent deflation and/or depression?

Buiter (2009) examines three radical ways to remove the zero bound on nominal interest rates. The first and the most straightforward is to abolish currency, existence of which is the source of the zero-bound constraint on nominal interest rates. This ensures that all money in the sense of means of payment or medium of exchange consists of registered instruments. Once all money holdings and 
their owners are known, the payment of positive or negative interest becomes easy. Abolishing currency may seem drastic at first glance, but this policy does not cause significant logistical problems in advanced economies, where most payments take nonmaterial forms anyway. Moreover, the abolishment could be a significant hindrance to the profitability from functioning in the underground economy.

The second is to tax currency in order to pay negative interest on it. This method has been exercised in the past using stamp script methods on banknotes. Buiter (2009) points out, that more high-tech ways than physically stamping bank notes are now available as means of identifying currency notes as current on interest due. Taxing currency is the most invasive of the three methods, as it removes some of the value of currency over time using costly administrative procedures. It is possible that no democratic government would be willing to commit to such policy, which is bound to be deemed utmost unpopular. The third method separates the numéraire function of currency from its means of payment/ medium of exchange function and introduces a variable exchange rate between a unit of the one-period safe non-monetary security denominated in terms of the numéraire and the currency/means of payment. A constant rate of devaluation permits the nominal interest rate in terms of the numéraire to be negative, even though the nominal interest rates in terms of the currency are still subject to the zero lower bound. None of the policies Buiter (2009) considers, however, seem even remotely likely to be adopted.

The financial crisis of 2007-2009 gives a new perspective on the neoclassical (linear-quadratic) monetary policy analysis approach. It seems that while it may give a reasonable calculation on how optimal monetary policy operates under fairly normal circumstances, this framework will not be suitable to analyze extraordinary crisis conditions. The financial disruptions that have been the subject of this article can have particularly nonlinear effects on the economy, because they can lead to an adverse spirals and accelerators. Therefore it could be argued, that monetary policy cannot minimize valuation risk, but it can reduce systemic risk. By easing monetary policy aggressively to offset the negative effects of financial crisis on aggregate economic activity - this includes both conventional and nonconventional monetary policy tools at the interest rate zero bound - monetary policy can reduce the likelihood that a financial stress might set off a financial accelerator and fire sales. The resulting reduction in uncertainty can then make it easier for the markets to collect the information that facilitates price discovery, thus speed up the return to normal market functioning of the sector.

Lastly, the federal government has exercised a new role as an insurer, lender, and investor to the financial system. It is important to note that exiting from these emergency measures may be very hard for the U.S government. When economies experience deep recessions, a typical occurrence is that they subsequently have very strong recoveries, often referred to as V-shaped recoveries. However, 
as Reinhart and Rogoff (2011) document, this V-shaped pattern is not characteristic of recessions that follow financial crises. This is so, because the deleveraging process takes a long time, resulting in weak revivals of the economy after the crisis. What is more, the intervention itself has aggravated the moral hazard problem faced by executives of large financial institutions. The renewed perception of being too important to fail could potentially lower their perception of the risks, lower equilibrium interest rates, and result in a similar financial crisis in the future. On top of that, it could be argued that historically governments acting as owners of companies often distort competition, not to mention other political economy considerations such as rent-seeking and plain corruption, which could become a significant problem in the more distant future.

The final lesson could come from history. At this point in time it seems that the countries with reliable financial systems, effective lenders of last resort and rigorous financial supervision and regulation did better in global financial crisis than others have (Bordo, Meissner 2011). Countries like Canada, Australia, Poland, and New Zealand whose banks were less exposed to financial innovations, whose banks did not have Special Investment Vehicles, and which did not have unregulated shadow banking systems largely avoided the recent crisis. Therefore, based on these natural counterfactuals, it could be argued that pursuing such policies should help avoiding similar crises in the future.

\section{Literature}

Ait-Sahalia Y., Adnritzky J., Jobst A., Nowak S., Tamirisa N. (2010), Market Response to Policy Initiatives During the Global Financial Crisis, „NBER Working Paper”, No. 15809 (March).

Baba N., Packer F. (2009), From Turmoil to Crisis: Dislocations in the FX Swap Market Before and after the Failure of Lehman Brothers, „Bank for International Settlements Working Paper No. 285 (July).

Bernanke B., Gertler M. (1989), Agency Costs, Net Worth, and Business Fluctuations, „American Economic Review", vol. 79 (March), pp. 14-31.

Bernanke B., Gertler M., Gilchrist S. (1996), The Financial Accelerator and the Flight to Quality, „Review of Economics and Statistics”, vol. 78 (February), pp. 1-15.

Bernanke B., Gertler M., Gilchrist S. (1999), The Financial Accelerator in a Quantitative Business Cycle Framework, [in:] John B. Taylor and Michael Woodford (eds.), Handbook of Macroeconomics, vol. 1, part 3, Amsterdam: North-Holland, pp. 1341-93.

Buiter W. (2009), Negative Nominal Interest Rates: Three Ways to Overcome the Zero Lower Bound, „The North American Journal of Economics and Finance”, 20 (3), 213-238.

Bordo M., Landon-Lane J. (2010), The Global Financial Crisis of 2007-08: Is it Unprecedented?, NBER Working Paper No. 16589, December

Caballero R. (2009), Complexity and Financial Panics, "NBER Working Paper", No. 14997 Issued in May

Campello M., Graham J., Harvey C. (2009), The Real Effects of Financial Constraints: Evidence from a Financial Crisis, „NBER Working Paper” No. 15552 (December). 
Christensen, J., Lopez J., Rudebusch G. (2009), Do Central Bank Liquidity Facilities Affect Interbank Interest Rates?, „Federal Reserve Bank of San Francisco Working Paper” No. 13 (June).

Cogan J., Taylor J. (2010), What the Government Purchases Multiplier Actually Multiplied in the 2009 Stimulus Package, „NBER Working Paper” No. 16505 (October).

Gagnon J., Raskin M., Remache J., Sack B. (2010), Large Scale Asset Purchases by the Federal Reserve: Did They Work?, „Federal Reserve Bank of New York Staff Report”, No. 441.

Goldberg L., Kennedy C., Miu J. (2010), Central Bank Dollar Swap Lines and Overseas Dollar Funding Costs, „National Bureau of Economic Research Working Paper” No. 15763.

Jordà O., Schularick M., Taylor A. (2010), Financial Crises, Credit Booms, and External Imbalances: 140 Years of Lessons, „NBER Working Paper” No. 16567 (December).

Lerner J., Tufano P., (2011) The Consequences of Financial Innovation: A Counterfactual Research Agenda, „NBER Working Paper” No. 16780 (February).

McAndrews J. (2009), Segmentation in the U.S. Dollar Money Markets During the Financial Crisis, „Paper presented at the International Conference of the Bank of Japan's Institute for Monetary and Economic Studies", Tokyo (May).

McAndrews J., Sarkar A., Wang Z. (2008), The Effect of the Long-Term Auction Facility o the London Inter-Bank Offered Rate, Federal Reserve Bank of New York Staff Report No. 335 (July).

Mishkin F. (2009), Is Monetary Policy Effective During Financial Crises, „American Economic Review", 99 (2), pp. 573-577.

Mishkin F. (2011), Monetary Policy Strategy: Lessons from the Crisis, „NBER Working Paper” No. 16755 (February).

Reinhart C., Reinhart V. (2011), Pride Goes Before a Fall: Federal Reserve Policy and Asset Markets, „NBER Working Paper” No. 16815 (February).

Reinhart C., Rogoff, K. (2011), A Decade of Debt, „NBER Working Paper” No. 16827 (February).

Sarkar A. Shrader J. (2010), Financial Amplification Mechanisms and the Federal Reserve's Supply of Liquidity During the Crisis, "Federal Reserve Bank of New York Staff Report" No. 431 (March).

Taylor J. (2009), Zrozumieć kryzys finansowy, PWN, Warszawa.

Taylor J., Williams J. (2009), A Black Swan in the Money Market, „American Economic Journal: Macroeconomics", 1(1), pp. 58-83.

Viral V. Acharya, Irvind Gujral, Nirupama Kulkarni, and Hyun Song Shin (2011), Dividends and Bank Capital in the Financial Crisis of 2007-2009, „NBER Working Paper” No. 16896.

$\mathrm{Wu}$ T. (2008), On the Effectiveness of the Federal Reserve's New Liquidity Facilities, „Federal Reserve Bank of Dallas Working Paper" (May). 